\title{
Classification Method fo Urban Solid Waste Disposal Sites
}

\author{
Adriana Soares de Schueler ${ }^{1}$, Claudio Fernando Mahler ${ }^{2}$ \\ ${ }^{1}$ Department of Architecture and Urbanism, Technology Institute, Federal Rural University of Rio e Janeiro, Seropédica, Brazil; \\ ${ }^{2}$ Program of Civil Engineering, COPPE, Federal University of Rio e Janeiro, Rio de Janeiro, Brazil. \\ Email: aschueler@ufrrj.br, cfmahler@acd.ufrj.br.
}

Received October 20 ${ }^{\text {th }}, 2010$; revised March 15 ${ }^{\text {th }}, 2011$; accepted April 25 ${ }^{\text {th }}, 2011$.

\begin{abstract}
One of the environmental liabilities left by abandoned urban waste disposal sites, closed without the correct procedures, is the risk of exposure to their effluents, whose emissions may occur for many years. The purpose of the proposed methodology, referred to as SISTAVAFE, an assessment system of a closed landfill, is to contribute in the risk assessment of exposure to leachate as well as to suggest procedures for site monitoring, according to different levels of care and urgency. The method is based on four matrices that help make an initial evaluation of the risk source, potential target and the surface and underground environmental paths. This paper only addresses the contamination caused by liquid effluents.
\end{abstract}

Keywords: Environmental Impact, Solid Waste Landfill, Later Occupation, Risk of Exposure, Leachate, Classification Tool, Multi-Criteria Analysis

\section{Introduction}

The daily disposal of approximately 150,000 tons of urban solid waste in Brazil (42\%) is inadequate in open dumps, wet sites, etc. In some cases, leachate seeps directly into the soil or creeks or rivers near the landfill, with risk of polluting those natural resources. Many closed waste dumps are concealed under topsoil with almost no environmental protection infrastructure.

In most cities, urban dynamics constantly causes an increase in unsuitable land use. When a waste disposal site is deactivated, its abandonment may be hazardous to the neighbouring environment and communities. The deactivation of areas used as waste dumps and later being reused without undergoing proper treatment not only devalues the vicinity, deteriorating the image of the town or city. It may even cause interruptions in the urban network, and expose the population to contamination, causing potential hazards of environmental degradation.

It is necessary to establish criteria for remediation and occupation of these areas, considering their specific characteristics, namely effluents and emissions (gas and leachate), geotechnical behaviour, topsoil capacity for vegetation, and exposure of future users to potential emissions. Even after such areas have been closed down, they may undergo consolidation processes for another 25 years or so due to the gas produced by decay of organic waste and the dead-load of the waste itself.

To close down these areas, a diagnosis should be made first of remaining environmental liabilities, then remediation measures should be proposed and the site be prepared for monitored intermediary occupation. Only when the aforementioned processes have stabilised can a new occupation, associated with a public utility, be prepared. Recently in Brazil there was a catastrophe in the town of Niterói. An old open dump was closed down and later occupied by the poor population. Homes were built, streets opened and, as time went by, the local government of Niteroi considered it a normal district, with electricity and drinking water infrastructure. On $7^{\text {th }}$ April 2010, after heavy rainfall, there was a catastrophic landslide with partial destruction of streets and houses causing the death of 231 people.

Authors such as Heitefuss, S. \& Keuffel Turk, A., (1994) and Pires (2011) /presented classification methodologies to decide on action relating to closed contaminated areas and open dumps. Mahler and Lima (2002) developed a methodology involving value analysis and fuzzy logics for selecting new landfill areas. Based on this concept, SISTAVAFE, an assessment system of a closed landfill, has been developed. This paper discusses the SISTAVAFE methodology and an example of as- 
sessment and classification of closed landfills, considering the risk of leachate reaching the population and/or natural resources, using the source-pathway-receptor approach developed herein. The aim was to provide the public administration with scientific tools for defining priority investments in environmental recovery of the old contaminated areas and waste disposal sites.

\section{Methodology}

\subsection{Risk}

Ogura (1995) includes a sequence of activities of prevention and preparation, in-line approach to the Disaster Mitigation Programme of UNDRO. These activities listed below can be considered elements of a risk management system:

- Hazard Assessment;

- Risk Analysis

- Disaster Prevention Measures;

- Emergency Planning

- Public Information and Training

The first three steps relate to preventive action and the last two stages with regard to preparation.

The identification and risk assessment steps aimed to take appropriate measures for elimination or reduction of risk situations. These steps depend on an accurate understanding of the processes of generating mass movements.

Ogura (1995) points out that the geological hazard as-

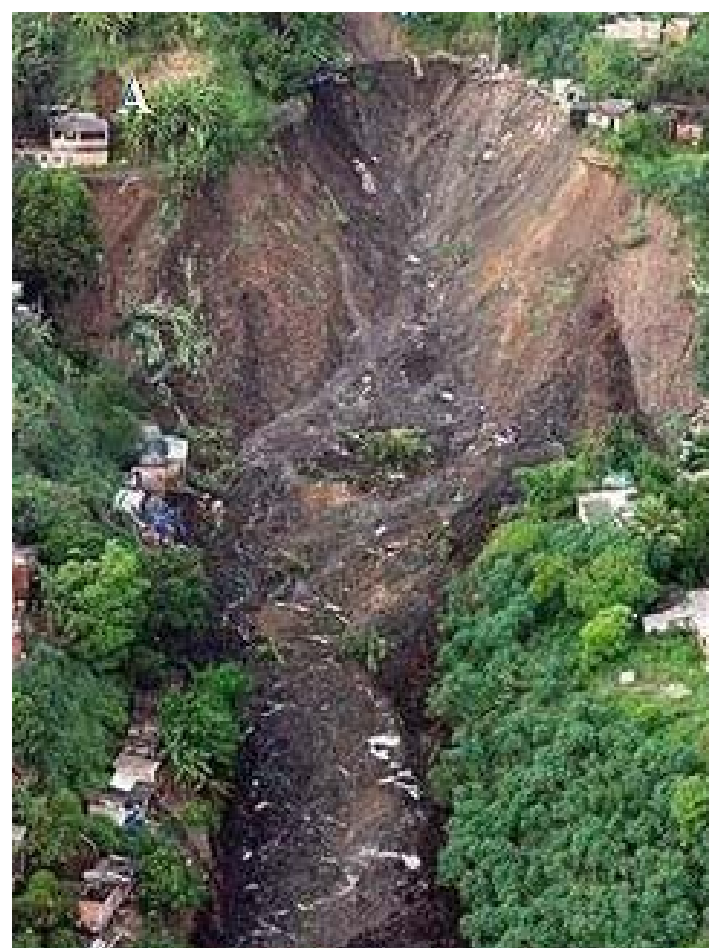

Figure 1. Landslide in Morro do Bumba, Niterói, Brazil (source: www.ambiencia.org) sessment (mass movements) begins by identifying and characterising the phenomenological type of geological process. Risks can be assessed in cases of specific or general risks.

Also in the stages of identification and risk assessment, areas are located where mass movements may occur (risk areas) in order to establish the conditions and circumstances of the occurrence of the processes (temporal resolution). Therefore, risk assessment helps locate, diagnose, categorize and map the risk status.

Fell (1994) and Fell \& Hartford (1997) present a risk management system applied to mass movements on slopes, consisting of a sequence of three basic steps:

- Hazard Assessment;

- Risk Analysis

- Actual Risk Assessment

According to this view risk management receives the information from the risk assessment and takes risk management action from decision making and risk monitoring.

Risk means a measure of the probability of a mass movement and intensity of adverse consequences for human health, property or the environment.

Risk is usually estimated by the product of the probability of the consequences. However, there are more general interpretations of the concept of risk comparisons involving probabilities and consequences of different forms of material between them.

Keaton \& Eckhoff (1989) define risk as the exposure of something of value to a risk situation. According to Einstein (1997) risk can be set using the following analytical expression:

$$
R=d \cdot u(\underline{X})
$$

where:

$R$ - Risk;

$d$ - probability of danger, if the mass movement;

$u(\underline{X})$ - is a utility function that expresses the costs of the consequences, which are the basis of these attribute vector $X$, which relates the consequences as the loss of lives, destruction of homes, housing the homeless, etc.

Ogura (1995) considers the product of risk probability /frequency of occurrence of a phenomenon of mass movement for the associated socio economic losses.

Keaton \& Eckhoff (1989) define risk as something to expose a dangerous situation. In this definition the English words "danger" and "hazard" are used as synonymous.

Public Policy” (1992) who defines risk as a function of two major factors: the probability that an event or series of events occurring and the consequence of these events and UNDRO-Office of the United Nations Disasters Relief Coordinator "(1979) defines risk as to the meaning of 
alleged number of lives lost, people injured, property damage and intervention in economic activity due to a particular phenomenon. Proceeds from the Specific Risk "and" Elements at Risk."

For a risk characterisation, a source - the waste landfill-and receptor-people and natural resources-are required. In a risk assessment the danger, exposure, assessment and its management should be identified. The question of exposure assessment in this case consists first of:

- Quality identification of leachate volume potentially produced in a waste landfill;

- Identification of the environmental pathways the leachate may follow until it reaches people or natural resources;

- Identification of the mobility of the leachate, which may affect the population and natural resources beyond the boundary of the waste disposal site

In this paper Risk is defined as the probability of occurrence of contamination caused by the leachate produced in the closed landfill. It was considered that a simple methodology of analyses of the different contamination possibilities could be an important tool to help the public administration to treat the question of contaminated areas.

The proposed methodology, SISTAVAFE involves establishing four matrices that together help guide each phase of the risks assessment of exposure of the leachate contamination to people and natural resources.

The result of the assessment will point to different levels of care in relation to the procedures to be taken on its closure and subsequent monitoring. The following parameters refer to:

- Contaminant source: Potential volume of leachate produced, which is influenced by the volume of waste landfill and the age of the last waste disposal. These are presented in the matrix 1 ;

- Pathways that the leachate may follow: They may be surface or subsurface.

Subsurface pathways are basically influenced by soil permeability and the thickness of the vadoze zone (the zone over the groundwater level).

Surface pathways are influenced by topography and morphology of the site, which may give rise to natural ponds, natural drainage and run-off. When ponds are created, the stagnated leachate tends to evaporate or seep in to contaminate the air and soil. When there is runoff, depending on the gradient, erosion may be caused by the impact of the liquid over the soil, with the risk of damaging the top layer of the landfill, which is generally poorly built and covers large distances. Both situations can be attenuated depending on its position in relation of the landfill. When the local water balance is negative, which means that the volume of precipitated water is less than the volume of evaporation (due to dry climate or presence of vegetation), the leachate produced by the waste landfill consists only of the natural moisture of the waste and of sub-products from the aerobic decay of organic waste matter.

- Subject of potential exposure: Human beings or animals living near the landfill, and natural resources;

The limit values used in the matrices were based on a two-year monitoring of the landfill studied (Schueler, 2005) and in value analysis methodology by interviewing ten different specialists.

The purpose of the proposed assessment system is to help identify the environmental liabilities left by solid waste disposal activities on a site and to establish procedures for its reintegration in a suitable urban context. The assessment is based on data collection guided by indicators of potential environmental and human health hazards. It should emphasise the use of existing data as far as possible, unless information is available for indicating the need for further detailed investigation. The collected data corresponds to specific points in the matrices, which provide results classified in accordance with the potential risk of leachate production, transportation and distance in a landfill. The result of the assessment will indicate the different levels of care in relation to the procedures to be taken on its closure and subsequent monitoring.

\section{Assessment Matrix}

Tables 1, 2, 3, 4 present the matrices built to specify the source, pathways and exposure of subjects.

\subsection{Source}

\subsubsection{Waste Leachate Production Assessment}

Source leachate production is controlled by biological decay of the waste. Although the divisions in stages in which the waste is being stabilised do not have strict time limits, three main ranges are considered:

Five years or less: The pollutants carried in the leachate generally reach maximum values in the first years of landfill operation (2 - 3 years) and gradually decrease during the subsequent years. This tendency can be generally applied to dissolved organic matter and principal inorganic ions (heavy metals, chloride, sulphate, etc.). (IPT/Cempre, 2000, and Andreotolla et al., 1997).

Five to thirty years: The speed of waste decay after reaching its maximum continues to slowly decline for 25 years or so (Tchobanoglous et al., 1993). These figures were obtained from gas measurements, where there is a relation with leachate production.

Over 30 years: At this age, it is no longer expected to produce a significant amount of gas, indicating that the stabilisation process of the waste is considerably ad- 
vanced, thereby reducing leachate production.

\subsection{Pathway}

\subsubsection{Assessment of Subsurface Pathway by Evaluating Landfill Base and Risk of Reach the Groundwater}

Five ranges of values for soil permeability $(\mathrm{K})$ are being considered. For permeability the maximum value of $10^{-3}$ $\mathrm{cm} / \mathrm{s}$ was adopted and low permeability is considered when it is more than $10^{-6} \mathrm{~cm} / \mathrm{s}$. Three medium intervals limited by the values, $10^{-3}$ and $10^{-6} \mathrm{~cm} / \mathrm{s}$ are being considered.

\subsubsection{Assessment of Surface Pathways, Local Geomorphology and Rainfall}

Table 3 provides the matrix for assessing surface hydrology. This matrix relates to the dynamics of surface hydrology - capacity for flooding or surface runoff, which includes water balance-and its location in relation to the landfill. Its purpose is to rate the natural drainage capacity of leachate and surface runoff water.

Topographic information, consisting of geomorphologic compartmentalization, characteristics of the units comprising relief, land slope and main processes acting on the region, such as erosion, landslide, flooding, and so on,

Table 1. Matrix 1 - for source assessment (leachate production).

\begin{tabular}{|c|c|c|c|c|c|}
\hline \multirow{2}{*}{ Volume of waste m3 } & \multicolumn{5}{|c|}{ Waste Landfill Assessment: Time since the last disposal at the landfill (years) } \\
\hline & Less than 6 & 6 to 12 & 12 to 18 & 18 to 24 & 24 to 30 or more \\
\hline Over 100,000 & 21 & 22 & 23 & 24 & 25 \\
\hline 60,000 to 80,000 & 16 & 17 & 18 & 19 & 20 \\
\hline 40,000 to 60,000 & 11 & 12 & 13 & 14 & 15 \\
\hline 20,000 to 40,000 & 6 & 7 & 8 & 9 & 10 \\
\hline Less than 20,000 & 1 & 2 & 3 & 4 & 5 \\
\hline
\end{tabular}

Table 2. Matrix 2 - for assessment of landfill base.

\begin{tabular}{|c|c|c|c|c|c|}
\hline \multirow{2}{*}{ Soil permeability $\mathrm{cm} / \mathrm{s}$} & \multicolumn{5}{|c|}{ Soil thickness until the ground water level (m) } \\
\hline & Until 1 & 1 to 2 & 2 to 3 & 3 to 4 & 4 to 5 \\
\hline Less than $10^{-3}$ & 21 & 22 & 23 & 24 & 25 \\
\hline $10^{-3}>\mathrm{k}>10^{-4}$ & 16 & 17 & 18 & 19 & 20 \\
\hline $10^{-4}>\mathrm{k}>10^{-5}$ & 11 & 12 & 13 & 14 & 15 \\
\hline $10^{-5}>\mathrm{k}>10^{-6}$ & 6 & 7 & 8 & 9 & 10 \\
\hline More than $10^{-6}$ & 1 & 2 & 3 & 4 & 5 \\
\hline
\end{tabular}

Table 3. Matrix 3 - for surface pathway assessment (topography and water balance).

\begin{tabular}{|c|c|c|c|c|c|}
\hline \multirow{3}{*}{ Water Balance } & \multicolumn{5}{|l|}{ Region characteristic } \\
\hline & \multicolumn{2}{|c|}{ Region subject to high-energy surface runoff } & \multicolumn{2}{|l|}{ Floodable region } & \multirow[b]{2}{*}{ On landfil } \\
\hline & $\begin{array}{c}\text { Downstream from } \\
\text { landfill }\end{array}$ & $\begin{array}{l}\text { Upstream from } \\
\text { landfill }\end{array}$ & $\begin{array}{l}\text { Upstream from land- } \\
\text { fill }\end{array}$ & $\begin{array}{c}\text { Downstream from } \\
\text { landfill }\end{array}$ & \\
\hline Positive all the year & 21 & 22 & 23 & 24 & 25 \\
\hline Positive 9 months/year & 16 & 17 & 18 & 19 & 20 \\
\hline Positive 6 months/year & 11 & 12 & 13 & 14 & 15 \\
\hline Positive 3 months/year & 6 & 7 & 8 & 9 & 10 \\
\hline Negative all the year & 1 & 2 & 3 & 4 & 5 \\
\hline
\end{tabular}


Table 4. Matrix 4 - for assessing the characteristics of urban zoning in the vicinity of the landfill.

\begin{tabular}{cccccc}
\hline & \multicolumn{5}{c}{ Use of the land } \\
Distance (m) & Protection Zoning & Housing/Commercial/industrial/services & Water Bodies & $\begin{array}{c}\text { Environmental } \\
\text { Preservation Zone }\end{array}$ & Agriculture \\
\hline Until 200 & 21 & $22(+1)$ & 23 & 24 & 25 \\
200 to 400 & 16 & $17(+1)$ & 18 & 19 & 14 \\
400 to 600 & 11 & $12(+1)$ & 13 & 9 & 15 \\
600 to 800 & 6 & $7(+1)$ & 8 & 3 & 5 \\
800 to 1000 & 1 & $2(+1)$ & 3 & & 5 \\
\hline
\end{tabular}

must be analysed, since there is a close relation between the relief and increase in environmental problems.

Gently sloping areas but with a natural difference in level or rise in order to minimise the surface water runoff into the landfill are recommended. Climate conditions must be considered. The monthly water balance calculated from data such as flood records, rainfall, sunlight and evapotranspiration is of the utmost importance for effluent generation in an urban solid waste landfill. Areas with heavy rainfall may increase leachate production.

The region tending to surface runoff with high energy flow (Figure 2) is where the sloping topographic characteristics are prone to strong surface runoff.

A - When this occurs downstream, the surface runoff that may be contaminated by the leachate will tend to go farther faster, which is a negative aspect.

B - When this occurs upstream from the landfill, an increase in water affecting the landfill may be found, contributing to further leachate formation, which is another negative aspect.

A floodable region is understood (Figure 3) to be where topographical characteristics are prone to flooding. In flooded places seepage and evaporation tend to occur.

C - Upstream from the landfill: When this occurs upstream from the landfill, seepage tends to recharge the aquifer with non-contaminated water through the leachate, which, in principle, can be considered a positive aspect.

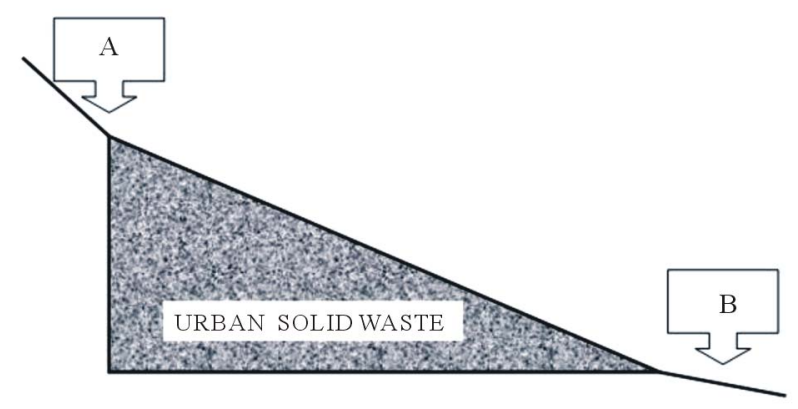

Figure 2. Diagram of alternatives of the category region subject to surface runoff with high-energy flow.

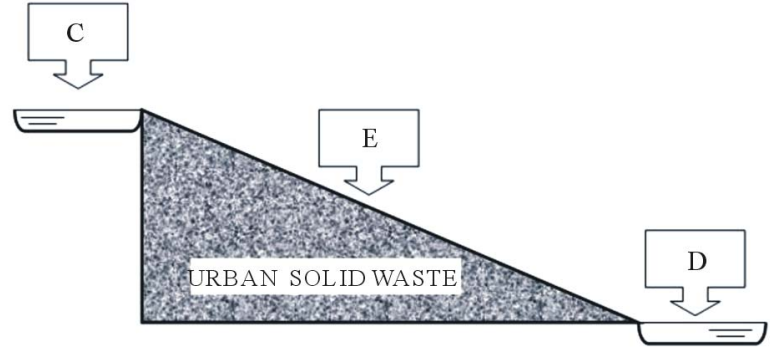

Figure 3. Diagram of alternatives of the floodable region category.

However, preferential flows may occur into the landfill, which may increase its moisture.

D - Downstream from the landfill: When the same situation occurs downstream from the landfill the flooded site may be contaminated by landfill leachate. In this case, the liquid seepage may cause

contamination of the topsoil until it reaches the aquifer or evaporates, which is shown to be a fairly negative aspect.

E - On the landfill: When the situation occurs on the landfill, seepage tends to increase its moisture and consequently leachate production.

When ratings were attributed from 1 to 25 using the qualitative criterion, the worst conditions are those when the positive water balance occurs in more months of the year.

\subsection{Subject Exposed}

\subsubsection{Assessment of Soil use Around Landfill}

The use of the land assessment matrix in Table 4 shows the proximity of occupation, type of population in contact with landfill effluents, and potentially affected natural resources. Its purpose is to rate the capacity of the effluents to reach the affected local population and special zones concerning the natural environment. Five kinds of use were considered relating to the landfill's proximity to protected environmental areas or water bodies, type of occupation by people (residential, industrial, commercial) and agricultural spaces (farm dwellers would 
stay there longer than urban dwellers).

Urban regions considered as Environmental Preservation Zones because of their characteristics and type of vegetation are intended for preservation and recovery of ecosystems, with a view to assuring space to maintain the diversity of the species and provide shelter for fauna as well as to protect springs and headwaters. The regions subject to special urban planning criteria are considered to be Protection Zones, which determine the occupation with a higher permeable rate, bearing in mind the public interest in environmental protection.

The proximity of the landfill to urban centres offers different levels of human exposure to the waste leachate. This contact may occur by contamination of the underground and surface water and soil, and by air, through air pollutants from the evaporation of the effluent. Contaminated water might be used for domestic animals and livestock slaughter, and for watering plants, including vegetable gardens, direct contact through wells, and even recreation. The surface-contaminated soil when leachate comes to the surface might be used in vegetable plots and gardens and even recreation areas. Apparently, the concentration of people in a certain physical space accelerates the environmental degradation processes, as normally happens in the case of low-income housing schemes. This is due to the poor sanitary conditions commonly found there, which cause more susceptibility to the influences of contact with the urban solid waste landfill. The lack of care is normal in such places both in relation to self protection and environmental protection, very often the result of the dwellers' lack of information and resources, and also considering the inspection problems of public authorities. When the residential area includes slums and low-income housing, one point is added to the equivalent rating.

Matrix values for assessment of land use ranged from 1 to 25 , linearly, so that where the special area or population's length of stay is shorter and farther from the urban solid waste landfill, it received lower ratings.

\subsection{Ratings}

The values were distributed in four matrices and each one contributes with $25 \%$. Matrix 1, referring to the potential leachate production; Matrix 2, referring to the capacity of leachate to reach the aquifer; Matrix 3, referring to the climate conditions influencing the production of effluent and to topographical conditions affecting the natural drainage capacity of the liquid coming to the surface or with surface runoff, and Matrix 4 referring to the natural resources and population potentially affected by contact with the effluent. Total points will be as follows:

Matrix $1+$ Matrix $2+$ (maximum value found in Matrix 3$)+($ maximum value found in Matrix 4)
The result will be used to classify the area in three categories, identified as Green, Yellow and Red, relating to the levels of post-closure environmental care. The limit values of the categories were calculated by adding up the values considered low, medium and high in the matrices. The quality reference value is considered to be the natural concentration of a substance in the soil and groundwater in the region, which had no contact with leachate.

Under 20 points: Green category

The initial assessment indicates landfills whose potential environmental contamination caused by its leachate is considered low. This is confirmed by chemical analyses of the groundwater, whose results must show concentration values that do not exceed regional references. Post-closure actions:

After performing the initial assessment of the area and diagnosing environmental hazards, (identifying air pollution, presence of waste collectors and animals, no compacted cover, scattered waste, breeding ground for mos quitoes, groundwater contamination, exposed populations, etc.) and information on the presence of leachate and its influence on its surroundings, it is important to consider the necessary level of recovery.

Normally the measures to be taken are the installation of a surface drainage system, removal of waste close to watercourses, or when the landfill is near flooded areas, building a percolate drainage system, installing gas drains, re-sloping and covering the waste.

a) Quarterly monitoring of groundwater during one year, in order to identify critical periods in relation to the possible presence of contamination.

b) Annual monitoring with chemical analysis of the groundwater for five years.

\section{1 - 60 points: Yellow category}

The initial assessment shows landfills whose potential environmental contamination caused by their leachate is considered average. This is confirmed by chemical analyses of groundwater, whose results show a higher concentration than the regional benchmarks. Post-closure actions:

Actions are required to protect the local environment. Quarterly monitoring of groundwater during one year in order to identify critical periods in relation to contamination of the aquifer and six-monthly monitoring with chemical analyses of the groundwater should be carried out until the results give values that do not exceed regional benchmarks.

After this, instructions for the Green b category must be followed.

61 - 100 points: Red category

The initial assessment shows landfills whose potential environmental contamination caused by their leachate is 
considered high. This is confirmed by chemical analyses of the groundwater, whose results must show concentration values equal to or higher than the Maximum Permissible Values for the substances, pursuant to the Ministry of Health Rule 518.

Post-closure actions: Urgent actions are required to protect the local environment. Quarterly monitoring of the groundwater with chemical analyses until the results show lower concentration values of contaminants than the Maximum Permissible Values for the substances as stated in the Ministry of Health Rule 18 for harmful substances present in the leachate.

Next, follow the instructions for the Yellow b category.

\section{Case of Study}

The method was applied in Paracambi waste landfill (Figure 4). It is almost like an open dump, located in Paracambi, a small town near Rio de Janeiro, Brazil, in an area covering approximately $25,000 \mathrm{~m}^{2}$ with a volume of approximately 59,000 $\mathrm{m}^{3}$. The landfill first received urban waste in 1969 and it was closed in 2005, when it was receiving about 26 tons a day of a large variety of waste.

The waste landfill is located at the foot of a hill. A river flows on the other side of the open dump at a distance of $50-70 \mathrm{~m}$. Houses occupy the area between the waste landfill and the river. The landfill is situated in an area that should be occupied by the natural spread of the town. The town centre is about one kilometre away on one side. Farther away on the other are the outskirts of Paracambi.

The final punctuation of Paracambi's waste landfill was $60(11+17+9+23)$, which includes it in the Yellow Category and indicates the presence of contamination, requiring remedial procedures. The score for the waste dump is Paracambi it presented in Tables $\mathbf{5}$ to $\mathbf{8}$.

The final punctuation of Paracambi's waste landfill was $60=11($ matrix 1$)+17($ matrix 2$)+9($ matrix 3$)$ +23 (matrix 4), what insert it in the Yellow Category and indicate presence of contamination and require remedia- tion procedures.

\section{Conclusions}

A site that has been used for USW disposal may continue producing effluents and contaminating the surroundingsfor years later. Measures must be taken to diminish leachate production and to monitor the groundwater of the surrounding area, even after taking remedial actions.

It should be considered that in Brazil sites used for waste disposal, after closure, sometimes become areas of potential interest for occupation by the low-income population. This is why it is important for those sites not to be simply abandoned but have a suitable destination in the urban context, being inspected to avoid their irregular occupation.

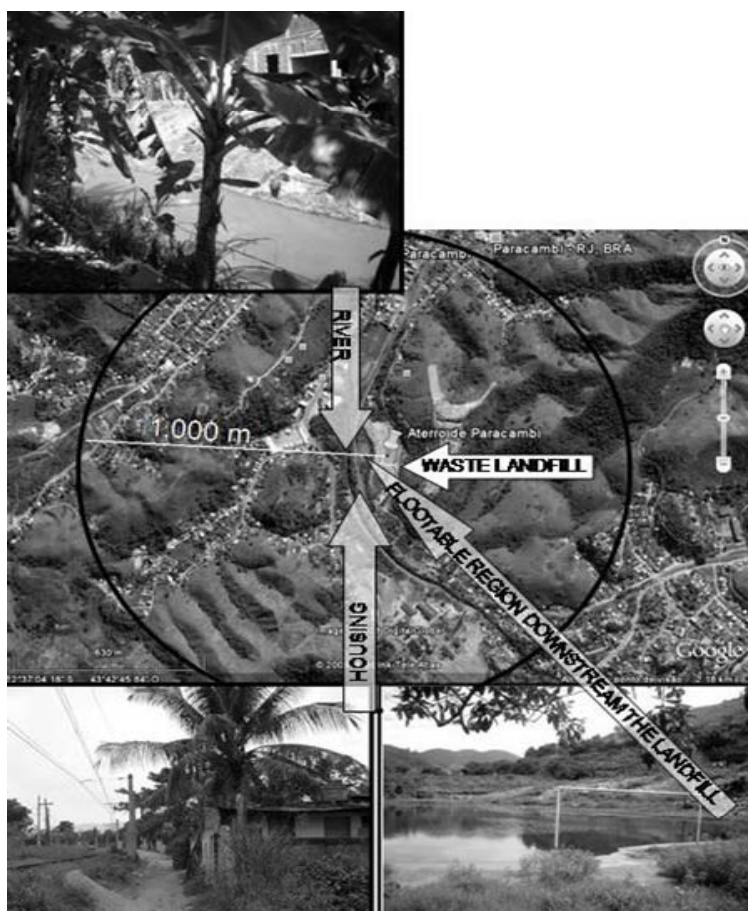

Figure 4. Image description of the area.

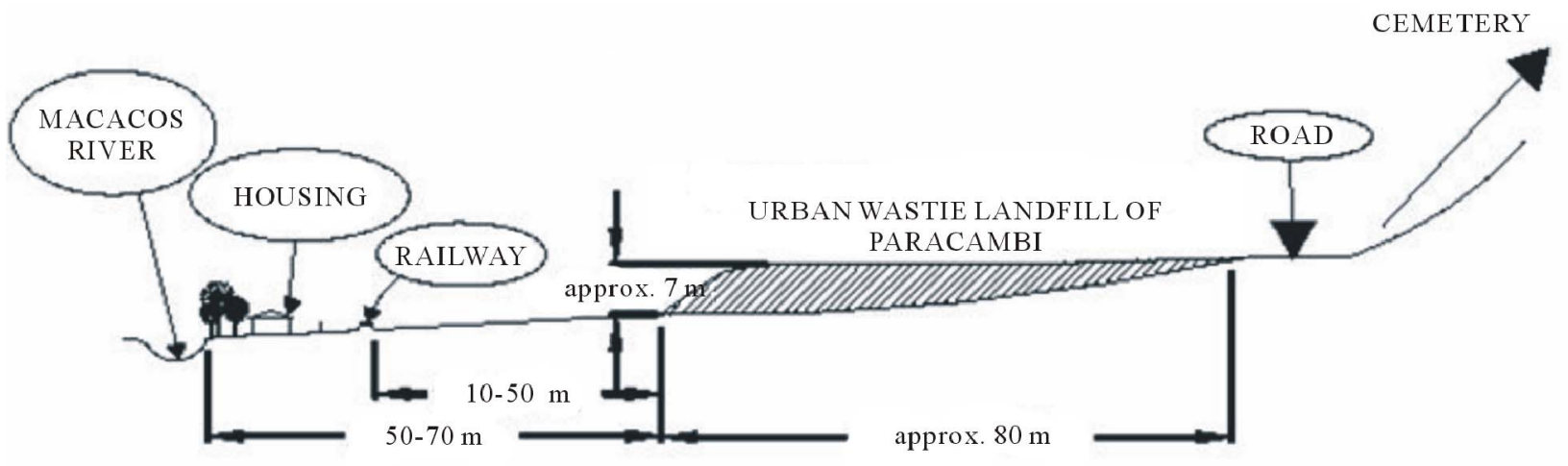

Figure 5. Sketch showing the location of the open dump in relation to the River. 
Table 5. Matrix 1: Source.

\begin{tabular}{|c|c|c|c|c|c|}
\hline \multirow{2}{*}{ Volume of waste m3 } & \multicolumn{5}{|c|}{ Waste Landfill Assessment: Time since the last disposal at the landfill (years) } \\
\hline & Less than 6 & 6 to 12 & 12 to 18 & 18 to 24 & 24 to 30 or more \\
\hline Over 100,000 & 21 & 22 & 23 & 24 & 25 \\
\hline 60,000 to 80,000 & 16 & 17 & 18 & 19 & 20 \\
\hline 40,000 to 60,000 & $\underline{11}$ & 12 & 13 & 14 & 15 \\
\hline 20,000 to 40,000 & 6 & 7 & 8 & 9 & 10 \\
\hline Less than 20,000 & 1 & 2 & 3 & 4 & 5 \\
\hline
\end{tabular}

Table 6. Matrix 2: Subsurface pathway.

\begin{tabular}{cccccc}
\hline \multirow{2}{*}{ Soil permeability cm/s } & \multicolumn{5}{c}{ Soil thickness until the ground water level (m) } \\
\cline { 2 - 5 } & Until 1 & 1 to 2 & 2 to 3 & 3 to 4 & 24 \\
\hline Less than $10^{-3}$ & 21 & 22 & 23 & 19 & 25 \\
$10^{-3}>\mathrm{k}>10^{-4}$ & 16 & $\underline{\mathbf{1 7}}$ & 18 & 13 & 15 \\
$10^{-4}>\mathrm{k}>10^{-5}$ & 11 & 12 & 8 & 9 & 4 \\
$10^{-5}>\mathrm{k}>10^{-6}$ & 6 & 7 & 3 & 4 & 5 \\
More than $10^{-6}$ & 1 & 2 & & 13 \\
\hline
\end{tabular}

Table 7. Matrix 3: Surface pathway.

\begin{tabular}{|c|c|c|c|c|c|c|}
\hline \multirow{3}{*}{\multicolumn{2}{|c|}{ Water Balance }} & \multicolumn{5}{|c|}{ Region characteristic } \\
\hline & & \multicolumn{2}{|c|}{$\begin{array}{l}\text { Region subject to high-energy surface } \\
\text { runoff }\end{array}$} & \multicolumn{3}{|c|}{ Floodable region } \\
\hline & & $\begin{array}{l}\text { Downstream from } \\
\text { landfill }\end{array}$ & $\begin{array}{l}\text { Upstream from } \\
\text { landfill }\end{array}$ & $\begin{array}{l}\text { Upstream from } \\
\text { landfill }\end{array}$ & $\begin{array}{c}\text { Downstream from } \\
\text { landfill }\end{array}$ & On landfill \\
\hline \multicolumn{2}{|c|}{ Positive all the year } & 21 & 22 & 23 & 24 & 25 \\
\hline \multicolumn{2}{|c|}{ Positive 9 months/year } & 16 & 17 & 18 & 19 & 20 \\
\hline \multicolumn{2}{|c|}{ Positive 6 months/year } & 11 & 12 & 13 & 14 & 15 \\
\hline \multicolumn{2}{|c|}{ Positive 3 months/year } & 6 & $\underline{7}$ & 8 & $\underline{9}$ & 10 \\
\hline \multicolumn{2}{|c|}{ Negative all the year } & 1 & 2 & 3 & 4 & 5 \\
\hline \multicolumn{7}{|c|}{ Table 8. Matrix 4: Subject exposed. } \\
\hline \multirow[b]{2}{*}{ Distance (m) } & \multicolumn{6}{|c|}{ Use of the land } \\
\hline & Protection Zoning & Housing/Com & rcial/industrial / services & Water Bodies & $\begin{array}{l}\text { Environmental } \\
\text { Preservation Zone }\end{array}$ & Agriculture \\
\hline Until 200 & 21 & & $\underline{22+1 *}$ & $\underline{23}$ & 24 & 25 \\
\hline 200 to 400 & 16 & & 17 & 18 & 19 & 20 \\
\hline 400 to 600 & 11 & & 12 & 13 & 14 & 15 \\
\hline 600 to 800 & 6 & & 7 & 8 & 9 & 10 \\
\hline 800 to 1000 & 1 & & 2 & 3 & 4 & 5 \\
\hline
\end{tabular}

*low income houses 
The proposed assessment system SISTAVAFE is a simple system that may also contribute to establishing criteria for the urban reintegration of such sites, creating guidelines for investigation areas and, consequently, optimising time and resources. Its application to a real case showed that it is a simple but valuable tool that should be used by many local governments worldwide for deciding on actions relating to closed landfills.

\section{Acknowledgements}

The authors thank CNPq and FAPERJ for their support.

\section{REFERENCES}

[1] Brazilian Technical Standards Association, "Non-Hazardous Waste Landfills_Criteria for Design, Implementation and Operation-Procedure (NBR-13896),” ABNTAssociação Brasileira de Normas Técnicas, Rio de Janeiro, 1997.

[2] G. Andreottola and P. Cannas, "Chemical and Biological Characteristics of Landfill Leachate,” In: T. H. Christensen, R. Cossu and R. Stegman, Eds., Landfilling of Waste: Leachate, 1997, pp. 65-88

[3] O. A. Filho, L. E. S. Cerri and C. J. Amenomori, “Geologic Risks. Conceptual Aspects,” I Simpósio Latino-Americano sobre Risco Geológico Urbano, São Paulo, 1990, pp. 334-341. (in Portuguese)

[4] R. Fell, "Landslide Risk Assessment and Acceptable Risk”. Canadian Geotechnical Journal, Vol. 31, 1994, pp. 261-272.

[5] R. Fell and D. Hartford, "Landslide Risk Management," Proceedings of the International Workshop on the Land- slide Risk Assessment, Hawaii, 19-21 February 1997, pp. 51-109.

[6] S. Heitefuss and K. Turk, "Additional Processing Notes for Establishing Regional Lists of Priorities and Regional Waiting Lists by the Regional Commission for Assessment A. Old Landfill Facts: First assessment of Old Landfill Disposal at Proof Level 1,” 1994, 8S., 7 Abb. (in German)

[7] IPT/CEMPRE "Local Waste: Handbook on Integrated Management,” Institute of Technological Research, 1st Edition, São Paulo, 2000.

[8] Mahler, C. F.; Lima, G. S. A. "Applying the value analysis and fuzzy logic to select areas for installing waste fills. Environmental Monitoring and Assessment” (EMA), 2002.

[9] A. T. Ogura, "Riesgos Geologicos Urbanos". Clases Dictadas en el Curso Formación en Aspectos Geológicos de Protección Ambiental. Instituto de Geociencias de la Universidad Estatal de Campinas - UNICAMP, São Paulo, Vol. 1, 1995, pp. 89-101.

[10] A. S. Schueler, "Case Study and Proposed Assessment of Degraded Areas by Disposal of Urban Solid Waste” Ph.D. Thesis, Coppe-Federal University of Rio de Janeiro (UFRJ). Rio de Janeiro, 2005.

[11] A. Pires, G. Martinho, N.-B. Chang, "Solid Waste Management in European Countries: A Review of Systems Analysis Techniques” Journal of Environmental Management, Vol. 92, No. 4, 2011, pp. 1033-1050.

[12] G. Tchobanoglous, H. Theisen and S. A. Vigil, "Integrated Solid Waste Management”, McGraw-Hill, New York, 1993.

[13] Ministry of Health Rule 518. 